\begin{tabular}{|l|l|l||}
\hline \multicolumn{2}{|c|}{ PublisherInfo } \\
\hline \hline PublisherName & $:$ & BioMed Central \\
\hline \hline PublisherLocation & $:$ & London \\
\hline \hline PublisherImprintName & $:$ & BioMed Central \\
\hline \hline
\end{tabular}

\title{
Oncostatin M: a key cytokine in arthritis
}

\begin{tabular}{|l|l|l||}
\hline \multicolumn{2}{|c|}{ ArticleInfo } \\
\hline \hline ArticleID & $:$ & 15 \\
\hline \hline ArticleDOI & $:$ & $10.1186 /$ ar-2000-66776 \\
\hline \hline ArticleCitationID & $:$ & 66776 \\
\hline \hline ArticleSequenceNumber & $:$ & 11 \\
\hline \hline ArticleCategory & $:$ & Paper Report \\
\hline ArticleFirstPage & $:$ & 1 \\
\hline \hline ArticleLastPage & $:$ & 3 \\
\hline \hline & & RegistrationDate : 2000-1-24 \\
\hline ArticleHistory & $:$ & OnlineDate \\
\hline \hline ArticleCopyright & $:$ & Current Science Ltd2000-1-24 \\
\hline \hline ArticleGrants & $:$ & \\
\hline \hline ArticleContext & $:$ & 130752211 \\
\hline \hline
\end{tabular}




\section{Keywords}

Oncostatin M, Proteoglycan, in vivo animal model

\section{Context}

Rheumatoid arthritis (RA) is a systemic inflammatory arthritis. Cytokines play a central role in the erosive process, resulting in lining layer hyperplasia and infiltration which in turn promote cartilage destruction. In vitro studies suggest interleukin (IL)-1 and OSM are important cytokines involved in cartilage destruction, and that they may act in synergy. To examine the effects of intra-articular injection of recombinant human OSM (rHuOSM) in vivo.

\section{Significant findings}

rHuOSM alone increased carpal : metacarpal ratio (joint swelling) and induced leukocyte infiltration and cartilage PG degradation in the goat joint. Injection of rHuOSM followed by rHuIL-1Ra resulted in a significantly higher rate of ex vivo PG synthesis; however, the effect of OSM on cartilage degradation in vivo did not change significantly with the subsequent injection of rHuIL-1Ra or rMuLBP.

\section{Comments}

This is an important paper, as previous reports have examined the effects of OSM, alone and in combination with other cytokines, in vitro only. This is the first in vivo study, and it also demonstrates that OSM acts independently of IL-1.

\section{Methods}

The right radiocarpal joints (RCJ) of 12 goats were injected with varying doses of rHuOSM, while the left RCJ were injected with saline as a control. In a further eight goats, both right and left RCJ were 
injected with rHuOSM, followed $1 \mathrm{~h}$ later by injection of recombinant human IL-1 receptor antagonist (rHuIL-1Ra) or recombinant murine leukaemia inhibitory factor binding protein (rMuLBP) in the right RCJ. Joint swelling was calculated by the ratio of the circumference of the carpal and metacarpal joints. The synovial fluid was assayed for leukocyte numbers and the cartilage assayed for proteoglycan (PG) content.

\section{References}

1. Bell MC, Carroll GJ, Chapman HM, Mills JN, Hui W: Oncostatin M induces leukocyte infiltration and cartilage proteoglycan degradation in vivoin goat joints. Arthritis Rheum. 2000, 42: 2543-2551.

This PDF file was created after publication. 